\title{
Desain Kapal Pengangkut LPG dengan Memanfaatkan Teknologi ISO TANK Untuk Memenuhi Kebutuhan di Kepulauan Karimunjawa
}

\author{
Kanda Nur Diansah \\ Departemen Teknik Perkapalan, Fakultas Teknologi Kelautan, Institut Teknologi Sepuluh Nopember \\ (ITS) \\ e-mail: kandanur7@gmail.com
}

\begin{abstract}
Abstrak-Karimunjawa merupakan sebuah kepulauan di Laut Jawa yang masuk ke dalam Kabupaten Jepara, Jawa Tengah, memiliki luas daratan $\pm \mathbf{1 . 5 0 0}$ hektare dan perairan $\pm \mathbf{1 1 0 . 0 0 0}$ hektare. Kepulauan Karimunjawa yang berpenduduk sekitar 10.000 jiwa membutuhkan pasokan gas LPG $3 \mathrm{~kg}$ sebanyak 4.380 tabung dan 301 tabung elpiji $12 \mathrm{~kg}$ dalam waktu satu bulan. Pasokan gas LPG ke Karimunjawa biasanya diangkut dengan menngunakan kapal kayu, kapal kayu dinilai tidak layak untuk digunakan mengangkut LPG karena faktor keselamatan yang sering terabaikan, serta tidak dapat berlayar pada waktu-waktu tertentu. Oleh karena itu diperlukannya sebuah solusi untuk mengatasi masalah tersebut, yaitu dengan dibuatnya desain kapal baru untuk mendistribusikan LPG ke Kepulauan Karimunjawa. Desain kapal akan menggunakan Self propeller barge, kapal barge jenis ini tidak seperti kapal barge pada umumnya yang ditarik atau didorong menggunakan bantuan kapal lain. Self propeller barge merupakan jenis barge yang memiliki mesin penggerak sendiri. Dari perhitungan teknis didapat ukuran utama kapal, panjang keseluruhan kapal adalah 30 meter dengan lebar 5,4 meter, tinggi 3,5 meter dan sarat 1,8 meter. Dari segi ekonomis diperoleh biaya pembangunan kapal sebesar Rp

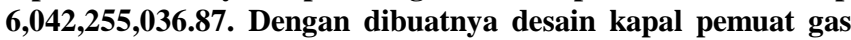
LPG dengan memanfaatkan teknologi ISO-TANK ini maka dapat meningkatkan faktor keselamatan dalam pendistribusian dan dapat terpenuhinya kebutuhan masyarakat di Kepulauan Karimunjawa.
\end{abstract}

Kata Kunci-Self Propeller Barge, LPG, ISO TANK.

\section{PENDAHULUAN}

B AHAN Bakar Gas (BBG) merupakan kebutuhan pokok masyarakat saat ini yang sangat diperlukan untuk memenuhi kebutuhan sehari-hari terutama jenis gas LPG dalam tabung. Namun akhir-akhir ini banyak terjadi kelangkaan di beberapa daerah khususnya di daerah-daerah kepulauan, salah satunya adalah kepulauan karimunjawa. Karimunjawa merupakan sebuah kepulauan di Laut Jawa yang masuk ke dalam Kabupaten Jepara, Jawa Tengah, memiliki luas daratan \pm 1.500 hektare dan perairan \pm 110.000 hektare. Tetapi saat ini terjadi masalah dalam proses pendistribusian gas LPG dalam tabung ke Karimunjawa yang mengakibatkan kelangkaan dan melonjaknya harga di wilayah tersebut [1].

Kepulauan Karimunjawa yang berpenduduk sekitar 10.000 jiwa membutuhkan pasokan gas LPG $3 \mathrm{~kg}$ sebanyak 4.380 tabung dan 301 tabung elpiji $12 \mathrm{~kg}$ dalam waktu satu bulan. Pasokan gas LPG ke Karimunjawa biasanya diangkut dengan menngunakan kapal kayu. Namun untuk sementara pengiriman pasokan gas LPG ke kepulauan karimunjawa mengalami masalah, karena kapal yang kayu biasa mengangkut LPG ke Kepulauan Karimunjawa dilarang beroperasi. Hal ini disebabkan oleh kebakaran kapal kayu bermuatan gas LPG dalam tabung beberapa bulan yang lalu. Sehingga menyebabkan dilarangnya penggunaan kapal kayu untuk mengangkut gas LPG ke Kepulauan Karimunjawa.

Selain itu kapal kayu dinilai tidak layak untuk digunakan mengangkut LPG karena faktor keselamatan yang sering terabaikan, serta tidak dapat berlayar pada waktu-waktu tertentu. Oleh karena itu diperlukannya sebuah solusi untuk mengatasi masalah tersebut. Dengan dibuatnya desain kapal pemuat gas LPG ini maka dapat meningkatkan faktor keselamatan dalam pendistribusian dan dapat terpenuhinya kebutuhan masyarakat di Kepulauan Karimunjawa [2].

\section{URAIAN PENELITIAN}

Dalam proses pengerjaan studi ini ada beberapa tahapan yang harus dilakukan. Adapun tahapan tersebut adalah sebagai berikut:

\section{A. Tahap Identifikasi}

Pada tahap ini dilakukan pengidentifikasian terhadap permasalahan yang ada yaitu permasalahan dalam proses pendistribusin LPG ke kepulauan karimunjawa yang selama ini masih menggunakan kapal kayu, kemudian ditentukan tujuan yang akan dicapai dalam studi ini. Serta melakukan penyusunan studi literatur yang dibutuhkan dalam studi ini.

\section{B. Tahap Pengumpulan dan Pengolahan Data}

Dilakukan proses pengumpulan data untuk menunjang proses analisis dalam studi ini. Kebutuhan data dibagi dalam kebutuhan data teknis dan kebutuhan data ekonomis. Proses pengumpulan data dapat berupa data primer ataupun data sekunder.

\section{Tahap Metodologi Penelitian}

Pada tahap ini dijelaskan mengenai alur pengerjaan dari studi ini atau proses desain kapal secara keseluruhan. Seluruh perencanaan dan analisis dalam proses mendesain kapal dilakukan secara berulang demi mencapai hasil yang maksimal ketika desain tersebut dikembangkan. Proses ini 
biasa disebut dengan proses desain spiral. Pada desain spiral proses desain dibagi ke dalam 4 tahapan, yaitu: concept design, prelimenary design, contract design, dan detail design.

1) Concept Design

Merupakan tahapan awal dalam proses desain dimana tahapan ini memiliki peranan untuk menerjemahkan owner requirement atau permintaan pemilik kapal ke dalam ketentuan dasar dari kapal yang akan didesain. Konsep bisa dibuat dengan menggunakan rumus pendekatan, kurva ataupun pengalaman untuk membuat perkiraan-perkiraan awal yang bertujuan untuk mendapatkan estimasi biaya konstruksi, biaya permesinan kapal dan biaya perlatan serta perlengkapan kapal. Hasil dari tahapan konsep desain ini umumnya berupa ukuran utama kapal, dan gambar secara umum.

\section{2) Prelimenary Design}

Adalah tahap lanjutan dari concept design. Tahapan ini merupakan tahapan pendalaman teknis lebih dalam yang akan memberikan lebih banyak detail pada konsep desain. Preliminary design ini merupakan iterasi kedua pada desain spiral. Adapun yang dimaksud detail meliputi fitur-fitur yang memberikan dampak signifikan pada kapal, termasuk juga pendekatan awal biaya yang akan dibutuhkan. Selain itu, proses yang dilakukan pada tahap ini antara lain adalah perhitungan kekuatan memanjang kapal, pengembangan bagian midship kapal, perhitungan yang lebih akurat mengenai berat dan titik berat kapal, sarat, stabilitas, dll. Pada tahap ini, dilakukan pemeriksaan yang terkait dengan performance kapal.

\section{3) Contract Design}

Merupakan tahapan dimana masih dimungkinkannya terjadi perbaikan hasil dari tahap preliminary design sehingga desain yang dihasilkan lebih detail dan teliti. Tujuan utama pada kontrak desain adalah pembuatan dokumen yang secara akurat dengan mendeskripsikan kapal yang akan dibuat. Selanjutnya dokumen tersebut akan menjadi dasar dalam kontrak atau perjanjian pembangunan antara pemilik kapal dan pihak galangan kapal. Adapun komponen dari contract drawing dan contract specification meliputi : arrangement drawing, structural drawing, structural details, propulsion arrangement, machinery selection, propeller selection, generator selection, electrical selection, dll. Seluruh komponen tersebut biasa juga disebut sebagai key plan drawing. Key plan drawing tersebut harus merepresentasikan secara detail fitur-fitur kapal sesuai dengan permintaan pemilik kapal.

\section{4) Detail Desain}

Dalam proses mendesain kapal, tahapan detail design merupakan tahapan yang terakhir. Dimana pada tahapan ini dilakukan pendetailan gambar key plan drawing menjadi production drawing atau gambar produksi yang nantinya akan digunakan sebagai gambar arahan kerja untuk membangun kapal. Tahap ini mencakupi seluruh rencana dan perhitungan yang diperlukan untuk proses konstruksi dan operasional kapal. Disamping itu pada tahap ini diberikan pula petunjuk mengenai instalasi dan detail konstruksi [3].

\section{Tahap Perhitungan Teknis dan Ekonomis}

Tahap ini merupakan tahap dimana dilakukannya perhitungan aspek teknis dari desain kapal pengangkut LPG dengan menggunakan Iso Tank yang meliputi perhitungan hambatan, stabilitas, titik berat, lambung timbul, trim, pembuatan rencana garis dan rencana umum serta permodelan 3D kapal. Selanjutnya dilakukan analisis ekonomis yang meliputi biaya pembangunan kapal, biaya oprasional kapal dan biaya investasi.

\section{E. Tahap Penarikan Kesimpulan dan Saran}

Pada tahap ini dilakukan penarikan kesimpulan dan saran dari analisis yang telah dilakukan pada tahap sebelumnya.

\section{ANALISIS TEKNIS}

LPG (Liquified Potreleum Gas) atau dapat diartikan sebagai gas minyak tanah yang di cairkan, dengan cara menambahkan tekanan dan menurunkan suhunya, maka dari yang semula berbentuk gas akan berubah menjadi bentuk cair. Menurut spesifiksinya LPG dibedakan menjadi tiga jenis yaitu LPG campuran, LPG propane dan LPG butana. LPG yang dipasarkan oleh Pertamina adalah LPG jenis campuran, LPG sendiri di pasarkan dalam bentuk cair di dalam tabung-tabung logam bertekanan. Dalam pemasarannya LPG tidak diisi secara penuh atau hanya sekitar $80 \%$ - 85\% dari kapasitasnya hal ini bertujuan untuk menghindari ekspansi panas.

Produksi LPG dalam negeri untuk keperluan domestik sekitar 2577 ton perhari, sedang kebutuhan sekitar 3500 ton perhari. Berdasarkan keputusan pemerintah yang mengkonversi minyak tanah ke LPG (Surat Keputusan Wakil Presiden RI no 20/WP/9/2006 tentang konversi minyak tanah ke LPG), oleh karena itu produksi LPG harus dimanfaatkan semaksimal mungkin untuk memenuhi kebutuhan dalam negeri.

Saat ini penggunaan LPG untuk keperluan domestik adalah $70 \%$ untuk rumah tangga, 17\% untuk industri, dan $13 \%$ untuk hotel dan rumah makan. Terdapat dua tipe pengangkut LPG yaitu, dalam kondisi pressurized ditekan pada tekanan $8-13 \mathrm{~kg} / \mathrm{cm}^{2}$ dengan suhu 28 derajat dan dalam kondisi refrigerated didinginkan pada suhu minus 42 derajat celcius dengan tekanan atmosfir.Kepulauan Karimunjawa sendiri membutuhkan pasokan LPG sebanyak 4.380 tabung untuk jenis LPG $3 \mathrm{~kg}$, dan sebanyak 301 tabung untuk jenis LPG $12 \mathrm{~kg}$ [4].

\section{A. Pemanfaatan Teknologi ISO TANK}

Semakin berkembangnya teknologi kontainer dimana saat ini kontainer juga dapat digunakan untuk mengangkut muatan cair dan gas (ISO TANK). Dengan memanfaatkan teknologi ISO TANK ini LPG dapat didistribusikan dengan aman, LPG akan dimasukkan kedalam ISO TANK dalam kondisi pressurized ditekan pada tekanan $8-13 \mathrm{~kg} / \mathrm{cm}^{2}$ dengan suhu 28 derajat.

Terdapat beberapa jenis yaitu ISO TANK tipe IMO - 1, IMO - 2, IMO - 3, IMO - 5 dan IMO - 7. Untuk proses pendistribusian LPG ke Kepulauan Karimunjawa akan digunakan ISO TANK tipe IMO - 5 yang khusus digunakan untuk mengangkut muatan dengan jenis gas [5]. 
Tabel 1. Spesifikasi ISO TANK IMO-5

\begin{tabular}{cc}
\hline \hline Kapasitas ISO TANK & $15000 \mathrm{~L}$ \\
Panjang & $6,05 \mathrm{~m}$ \\
Lebar & $2,4 \mathrm{~m}$ \\
Tinggi & $2,4 \mathrm{~m}$ \\
\hline \hline
\end{tabular}

\section{B. Penentuan Payload dan Ukuran Utama Awal}

Proses penentuan payload didapat dari jumlah kebutuhan LPG di Kepulauan Karimunjawa. Untuk perhitungan dalam deadweight tonnage payload akan diberikan margin $10 \%$. DWT $=$ Payload $+10 \%$ x Payload

Dan dari perhitungan yang telah dilakukan didapat payload kapal sebesar 50 ton dan DWT kapal sebesar 55 ton. Untuk penentuan ukuran utama awal kapal digunakan metode puzzle dan berdasarkan data spesifikasi iso tank yang akan digunakan maka di dapat ukuran utama awal kapal sebagai berikut:

Table 2.

Ukuran utama awal kapal

\begin{tabular}{lc}
\hline & Ukuran utama awal kapal \\
\hline Panjang & $30 \mathrm{~m}$ \\
Lebar & $5,4 \mathrm{~m}$ \\
Tinggi & $3,5 \mathrm{~m}$ \\
Sarat & $1,8 \mathrm{~m}$ \\
\hline \hline
\end{tabular}

\section{Perhitungan Hambatan}

Pada perhitungan hambatan ini dilakukan dengan menggunakan dua metode yang pertama perhitungan hambatan dilakukan menggunakan metode holtrop dan dari perhitungan hambatan dengan metode holtrop diperoleh nilai-nilai hambatan sebesar $6,459 \mathrm{KN}$. Perhitungan hambatan yang kedua menggunakan rumus-rumus perhitungan hambatan untuk kapal barge, sesuai dengan KRS rules tahun 2011 mengenai towing survey of barges and tugboats. Rumus perhitungan yang digunakan dalam menentukan harga hambatan total sebagai berikut:

$$
\begin{aligned}
& R_{\text {tot }}=R_{f}+R_{w}+R_{a} \\
& R_{f}=0.000136 F_{1} A_{1} V^{2} \\
& R_{w}=0.014 C F_{2} A_{2} V^{2} \\
& R_{a}=0.0000195 C_{g} C_{H} A_{a}\left(V_{w}+V\right)^{2}
\end{aligned}
$$

Table 3 . Hasil perhitungan hambatan kapa

\begin{tabular}{ccc}
\hline \hline \multicolumn{3}{c}{ Resistance and Power Summary } \\
\hline $\mathrm{R}_{\mathrm{f}}$ & 13.628 & $\mathrm{kN}$ \\
$\mathrm{R}_{\mathrm{w}}$ & 40.917 & $\mathrm{kN}$ \\
$\mathrm{R}_{\mathrm{a}}$ & 19.667 & $\mathrm{kN}$ \\
$\mathrm{R}_{\mathrm{T}}$ & 74.212 & $\mathrm{kN}$ \\
$\mathrm{EHP}$ & 305.399 & $\mathrm{Kw}$ \\
$\mathrm{DHP}$ & 512.806 & $\mathrm{Kw}$ \\
$\mathrm{BHP}$ & 610.927 & $\mathrm{Kw}$ \\
\hline \hline
\end{tabular}

\section{Perhitungan Berat Kapal}

\section{1) Perhitugan Beban}

Perhitungan beban pada kapal ini dilakukan secara pos per pos dengan rumus-rumus yang digunakan mengacu pada BKI volume 2 section 4. Perhitungan dilakukan pada tiga bagian yaitu beban pada bagian sisi kapal, dasar kapal dan pada bagian geladak kapal. Berikut ini adalah rekapitulasi hasil perhitungan beban yang telah diperoleh :

- Beban pada sisi kapal $=24.812 \mathrm{kN} / \mathrm{m}^{2}$

- Beban pada dasar kapal $=28.541 \mathrm{kN} / \mathrm{m}^{2}$

- Beban pada geladak kapal $=6.384 \mathrm{kN} / \mathrm{m}^{2}$

2) Perhitungan Tebal Pelat

Dari perhitungan beban yang telah diperoleh maka dapat ditentukan tebal pelat yang akan digunakan. Tebal pelat yang akan digunakan adalah sebagai berikut :

- Tebal pelat pada daerah sisi kapal $=8 \mathrm{~mm}$

- Tebal pelat pada daerah dasar kapal $=8 \mathrm{~mm}$

- Tebal pelat pada daerah geladak $=6 \mathrm{~mm}$

3) Perhitungan Berat Baja

Pada perhitungan berat baja kapal dibagi menjadi empat bagian yaitu bagian lambung, geladak, bangunan atas (superstructure) dan untuk penegar kapal. Hasil perhitungan berat baja kapal dapat dilihat sebagai berikut :

- Berat lambung kapal $=16.929$ ton

- Berat geladak kapal =4.311on

- Berat bangunan atas $=4.740$ ton

- Berat penegar = 7.794 ton

- Total berat baja kapal $=33.774$ ton

4) Perhitugan crew and consumable

Pada perhitungan ini ditentukan jumlah crew dan kebutuhan selama pelayaran. Hasil yang diperoleh dari perhitungan adalah sebagai berikut :

- Jumlah crew = 11 orang

- Total berat consumable $=3.742$ ton

- Titik berat consumable $=21.074 \mathrm{~m}$ dari FP

5) Perhitungan berat peralatan dan perlengkapan

Perhitungan berat peralatan dan perlengkapan ini mengacu pada Ship Design Effeciency and Economy tahun 1998. Dari perhitungan yang telah dilakukan diperoleh berat dari peralatan dan perlengkapan sebesar 24.170 ton dan titik berat 19.814 meter dari FP.

\section{E. Total Berat dan Titik Berat Kapal}

Untuk menghitung berat pada kapal dilakukan perhitungan terhadapa LWT dan DWT, dimana uktuk LWT terdiri dari beberapa komponenen yaitu berat baja kapal, berat peralatan, berat permesinan, berat mesin cadangan, sedangkan unt DWT terdiri dari payload, berat bahan bakar dan pelumas, berat air tawar, berat provision, serta berat orang dan bawaan, nantinya untuk memperoleh displasmennya jumlah dari seluruh komponen LWT akan dijulhkan dengan jumlah seluruh komponen DWT, lalu nantinya nilia dari jumlah tersebut akan dibandingkan dengan displasmen awal kapal, dimana untuk kriteria displasmennya mememnuhi margin antara keduanya berada diantara $0 \%-10 \%$, untuk detail perhitungan dapat dilihat pada lampiran, berikut merupakan rekap hasil perhitungan. Dari perhitungan-pehitungan berat yang telah dilakukan, diperoleh hasil sebagai berikut :

- Berat LWT = 84.701 ton

- Berat DWT = 55.2816 ton

- Total berat = 139.983 ton

- Koreksi terhadap displacement $=5 \%$ (Accepted $)$

\section{F. Perhitungan Lambung Timbul}

Perhitungan lambung timbul pada kapal ini mengacu pada Non Conventional Vessel Standard (NCVS) oleh Kementerian Perhubungan Republik Indonesia. Dari 
Perhitungan diketahui bahwa besar lambung timbul yang disyaratkan adalah $0.29 \mathrm{~m}$, dan kondisi lambung timbul sebenarnya dari kapal adalah $1.70 \mathrm{~m}$. Karena lambung timbul kapal lebih besar dari lambung timbul yang di syaratkan maka koreksi lambung timbul kapal telah memenuhi.

\section{G. Pembuatan Rencana Garis}

Pembuatan rencana garis dimulai dengan pembuatan model pada software maxsurf, pembuatan model disesuaikan dengan ukuran utama kapal yang telah diperoleh dari hasil perhitungan. Setelah proses pembuatan model selesai maka selanjutnya adalah menentukan jarak station, waterline, dan baseline agar didapat gambar rencana garis yang dapat dilihat dari depan, samping dan atas [6].

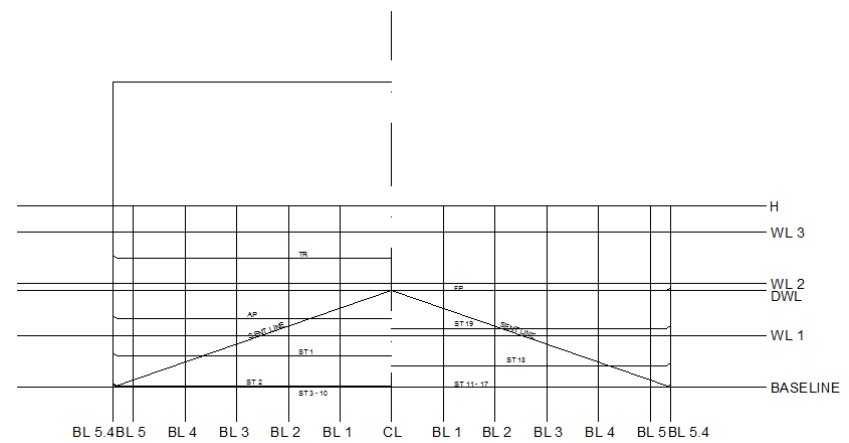

Gambar 1. Body Plan

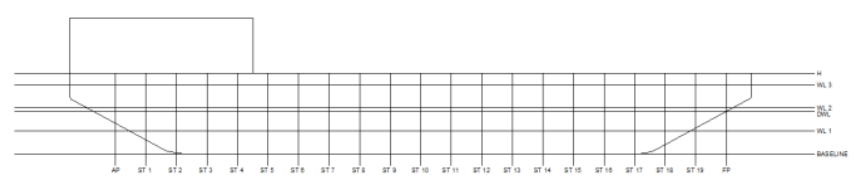

Gambar 2. Sheer Plan

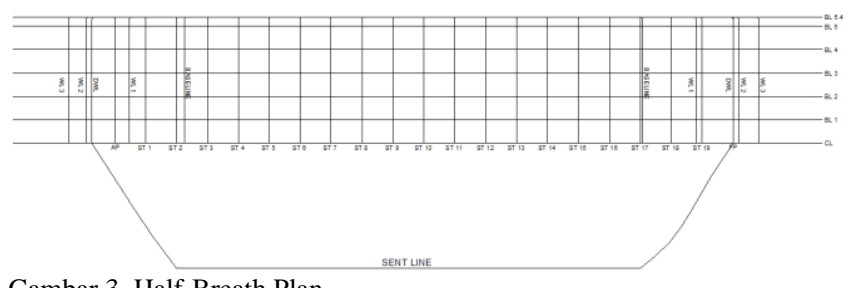

Gambar 3. Half-Breath Plan

\section{H. Pembuatan Rencana Umum}

Rencana umum berisi pengaturan pelatakan ruangan, perlengkapan dan peralatan, serta pembagian sekat. Self Proppled Barge (SPB) pengangkut ISO TANK ini memeliki ruang muat yang berada di atas deck sepanjang 17.9 meter dengan lebar 5.4 meter (selebar kapal). Pembutan rencana umum menggunaka bantuan software AutoCad, rencan umum ini dibuat dalam tiga pandangan yaitu tampak depan, smaping dan atas.
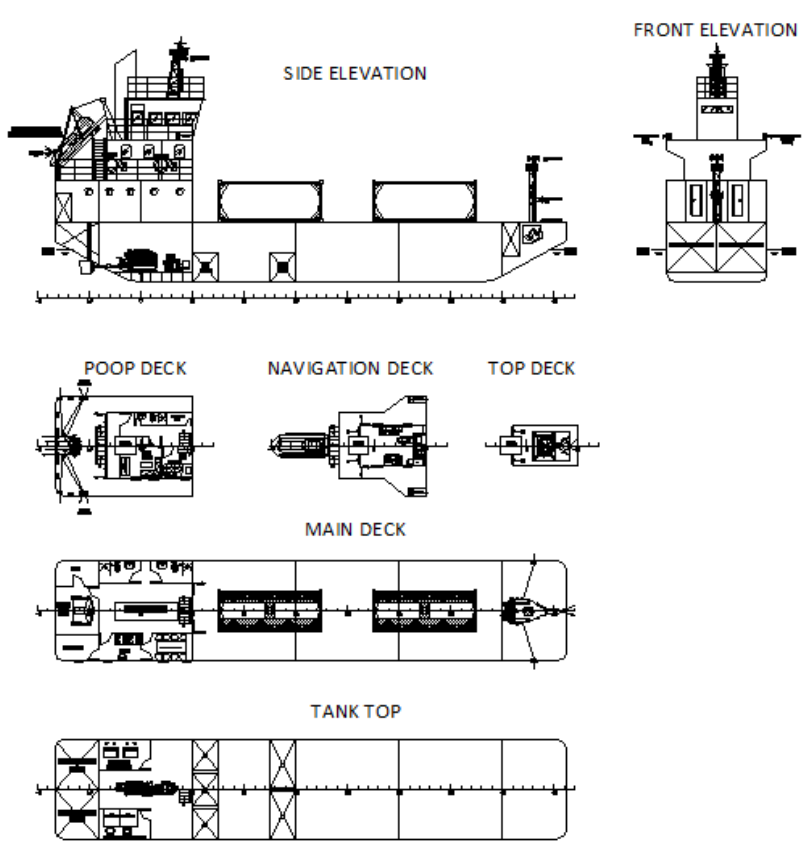

Gambar 4. Rencana Umum

\section{Permodelan 3D}

Permodelan 3D dilakukan dengan menggunakan software sketch up. Proses pertama yaitu dengan import model dari software Maxsurf Modeller, selanjutnya tingal menambahkan beberapa item yang ada pada kapal.

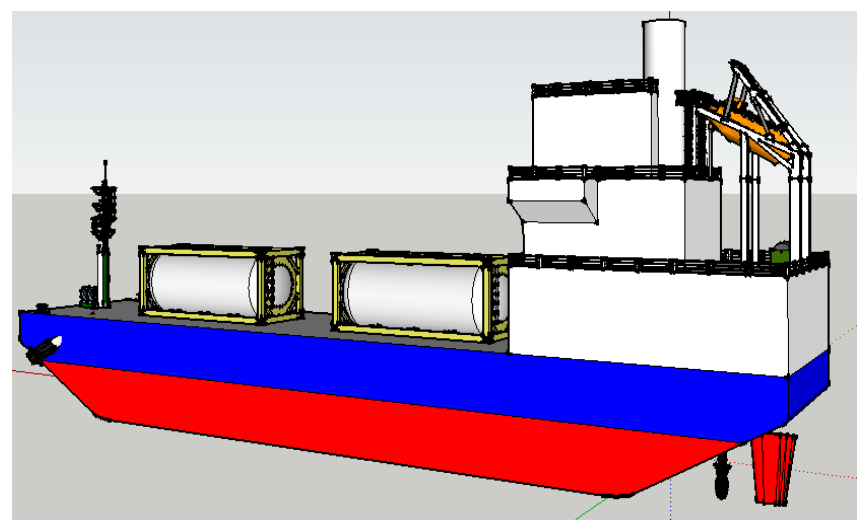

Gambar 5. Permodelan 3D Kapal tampak samping

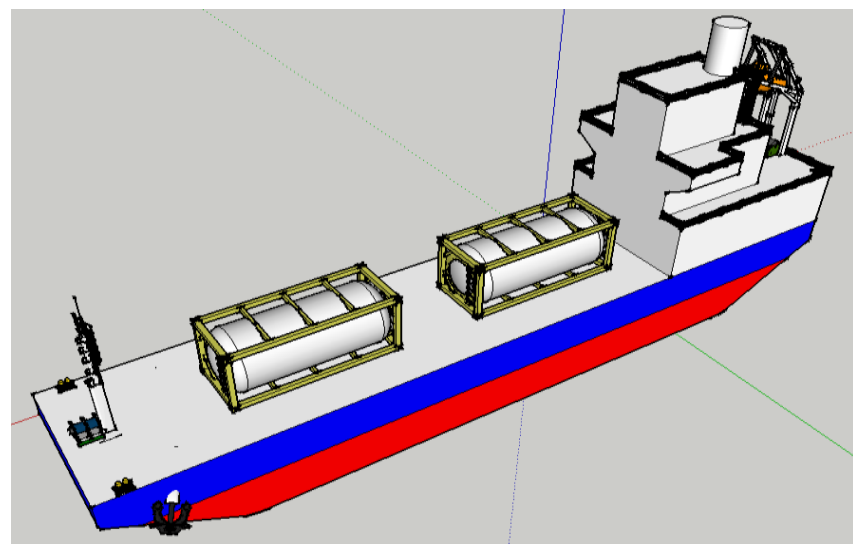

Gambar 6. Permodelan 3D Kapal tampak atas 


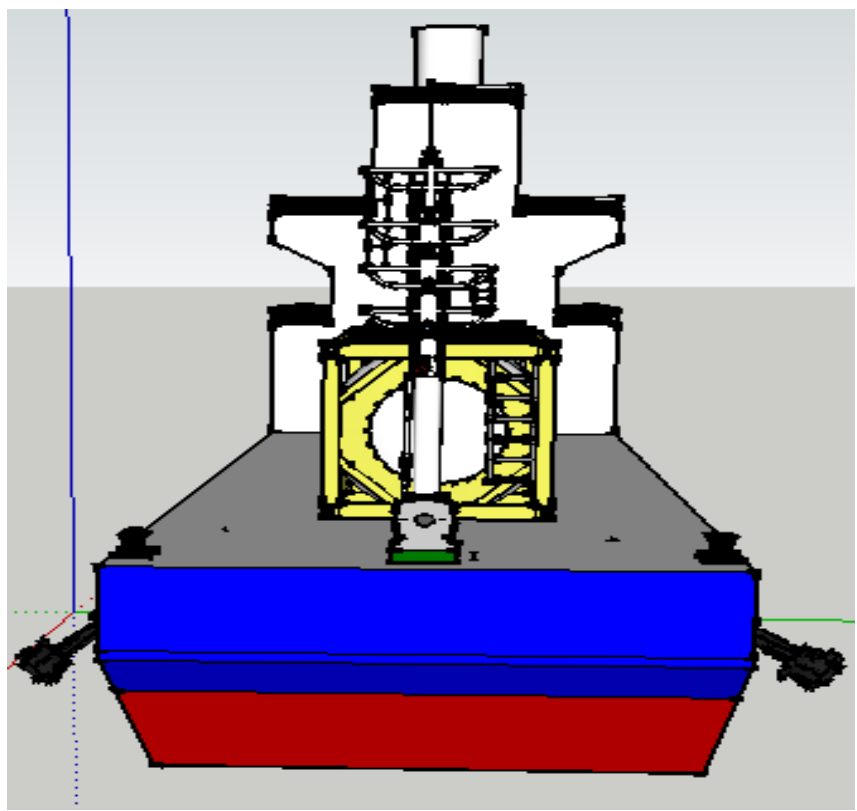

Gambar 7. Permodelan 3D Kapal tampak depan

\section{ANALISIS EKONOMIS}

Pada penghitungan analisis ekonomis, yang dilakukan ialah menghitung biaya yang dibutuhkan untuk proses pembangunan dan biaya oprasional kapal. Analisis ekonomis disini meliputi :

\section{A. Biaya Pembangunan Kapal}

Pada penghitungan biaya pembangunan, yang dilakukan ialah menghitung biaya total pembanguanan berdasarkan kebutuhan terhadap suatu item dikali dengan harga dari item, setelah diperoleh nilai keseluruhan biaya pembelian kapal dijumlah dengan biaya pembelian item-item yang diperlukan pada kapal. Penjumlahan keduanya nanti akan ditambah lagi dengan beberpa koreksi diantaranya koreksi keuntungan galangan sebesar $10 \%$, koreksi nilai inflansi mata uang sebesar $2 \%$, dan biaya pajak pemerintah sebesar $10 \%$, setelah diperoleh nilai keseluruhanya, lalu dijumlah maka diperoleh biaya pembangunan/konversi kapal.

Setelah dilakukan perhitungan dan koreksi maka diperoleh biaya total pembangunan kapal pengangkut ISO TANK sebesar Rp 5,874,866,241.28 atau sebesar USD 419,633.30.

\section{B. Biaya Oprasional Kapal}

Biaya operasi merupakan nilai yang harus dikeluarkan untuk pembiayaan kapal ketika sedang beroperasi dalam kurun waktu tertentu, adapun yang diperhitungkan dalam biaya operasi kapal nilai cicilan terhadap bank yang dipinjam ketika proses pembangunan kapal, gaji crew kapal, biaya perawatan kapal, dan biaya asuransi, dalam perhitungan ini periode waktu yang digunakan adalah selama satu tahun. Biaya oprasional kapal setelah dilakukan perhitungan adalah sebesar Rp 2,080,408,104.

\section{Biaya Investasi}

Biaya untuk investasi mencakup biaya yang harus dikeluarkan dan pendapatan yang akan diterima dalam suata kegiatan. Dalam perhitungan ini ditetapkan harga LPG sesuai dengan harga resmi yang ditentukan oleh Pertamina, yaitu Rp 20,000 per tabung untuk LPG $3 \mathrm{~kg}$ dan Rp 130,000 per tabung untuk LPG $12 \mathrm{~kg}$. Kemudian harga tersebut dikalkulasi dengan jumlah kebutuhan LPG selama satu tahun di Kepulauan Karimunjawa. Dan dikurangi dengan biaya pembangunan kapal serta biaya oprasional kapal selama satu tahun.

Setelah dilakukan perhitungan NPV maka didapat nilai sebesar Rp 1,437,447,835.14. Karena nilai NPV > 0 maka dapat disimpulkan bahwa pembangunan kapal pengangkut LPG dengan memanfaatkan teknologi ISO TANK ini layak untuk dilakukan.

\section{KESIMPULAN}

Berdasarkan analisis teknis dan ekonomis yang telah dilakukan maka di dapat hasil sebagai berikut:

1. Payload untuk kapal pengangkut LPG dengan memanfaatkan teknologi ISO TANK menuju Kepulauan Karimunjawa sebesar 50.256 ton. Rute pelayaran dari pelabuhan di Semarang menuju pelabuhan di Kepulauan Karimunjawa dengan jarak tempuh pelayaran adalah 70.734 mil laut

2. Ukuran utama kapal yang diperoleh adalah :

- $\mathrm{Lwl}=27,6 \mathrm{~m}$

- $\mathrm{Lpp}=26,6 \mathrm{~m}$

- $\mathrm{B}=5,4 \mathrm{~m}$

- $\mathrm{H}=3,5 \mathrm{~m}$

- $\mathrm{T}=1,8 \mathrm{~m}$

3. Besar biaya pembangunan kapal pengangkut LPG dengan memanfaatkan teknologi ISO TANK menuju Kepulauan Karimunjawa adalah sebesar Rp 5,874,886,241.28 atau sebesar USD 419,633.30.

4. Penentuan ukuran utama yang perlu dianalisis lebih lanjut, dikarenakan tidak adanya kapal pembanding dalam proses penentuan ukuran utamam kapal.

\section{DAFTAR PUSTAKA}

[1] Wikipedia, "Kepulauan karimunjawa," wikipedia website, 2016. [Online]. Available: https//id.wikipedia.org.

[2] Supriyadi, "BBM dan Gas Elpiji Langka, Warga Karimunjawa Berniat Datangi Bupati Jepara," Koran Jepara, Jepara, 2016.

[3] F. Systems, "R \& D," 2015. [Online]. Available: friendshipsystems.com.

[4] A. Muis, "Alternatif Kapal Pengangkut LPG Melalui Sungai Dengan Memanfaatkan Teknologi ISO-TANK," Sains dan Teknol. Indones., vol. 8, no. 2, pp. 57-61, 2011.

[5] EK-TAINER, "Containers Specification and Technical Data," http://www.ektainers.com, 2017. [Online]. Available: http://www.ektainers.com.

[6] M. R. Hafiz, "Desain Kapal Penumpang Barang Untuk Pelayaran Gresik-Bawean,” ITS, 2014. 